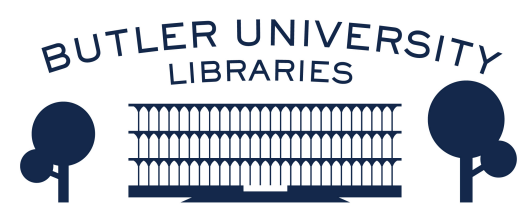

Journal of Hindu-Christian Studies

Volume 20

Article 22

January 2007

\title{
Book Review: "The Immanent Divine: God, Creation, and the Human Predicament"
}

Reid B. Locklin

Follow this and additional works at: https://digitalcommons.butler.edu/jhcs

Part of the Religion Commons

\section{Recommended Citation}

Locklin, Reid B. (2007) "Book Review: "The Immanent Divine: God, Creation, and the Human Predicament"," Journal of Hindu-Christian Studies: Vol. 20, Article 22.

Available at: https://doi.org/10.7825/2164-6279.1397

The Journal of Hindu-Christian Studies is a publication of the Society for Hindu-Christian Studies. The digital version is made available by Digital Commons @ Butler University. For questions about the Journal or the Society, please contact cbauman@butler.edu. For more information about Digital Commons @ Butler University, please contact digitalscholarship@butler.edu. 
style, The Asian Jesus represents a particularly valuable resource for use in the undergraduate classroom.
Reid B. Locklin

University of Toronto

\section{The Immanent Divine: God, Creation, and the Human Predicament. John J. Thatamanil, Minneapolis: Fortress Press, 2006, $231+$ xxi pages.}

JOHN J. Thatamanil, assistant professor of Theology at Vanderbilt University, offers readers a sustained comparative study of the $8^{\text {th }}$ century Advaitin teacher Adi Shankaracharya and the $20^{\text {th }}$-century Protestant theologian Paul Tillich. As a significant contribution to the emerging field of comparative theology, his project works on at least three interrelated levels.

At a basic level, Thatamanil advances a strong claim about comparative method, defending "the human predicament" as a fruitful category for Hindu-Christian studiessufficiently "vague" to treat otherwise incommensurable claims, but also sufficiently well-defined to permit substantive enquiry. Despite their considerable historical, social and philosophical distance, Thatamanil maintains, both Shankara and Tillich can be analysed in terms of ". . . (1) a diagnosis of the human predicament, (2) an etiology of the human predicament, (3) a prognosis, and finally (4) a therapy for treating and perhaps even wholly curing the disease" (17). Chapters 2 and 3 thus survey Shankara's accounts of suffering and samsara (diagnosis), beginningless ignorance as their cause (etiology), the teaching of nondualism (therapy), and the promise of liberation through self-knowledge in this very life (diagnosis). Chapters 4 and 5, in turn, develop Tillich's distinctive approach to comparable issues, including human estrangement from our divine ground (etiology), the consequent distortion of desire and tendency to self-destructive egoism (diagnosis), "ecstatic healing" through the gift of the Spirit (therapy) and the real, though never completely secure, possibility of sanctification (prognosis). Along the way, without papering over major differences, Thatamanil draws compelling parallels and thus convincingly demonstrates the usefulness of asking questions of soteriology and theological anthropology across religious boundaries.

Taken only thus far, The Immanent Divine already represents a notable achievement, albeit one deeply (and explicitly) rooted in the prior contributions of Robert Cummings Neville and the Comparative Religious Ideas Project at Boston University. At a second level, however, Thatamanil also uses his comparative method to challenge the purportedly "unbridgeable chasm" that, according to many interpreters, divides the "dualistic" West from the "mystic" and/or "pantheistic" East. In his conclusion (ch. 6), for example, he argues that it would be "premature" to judge these two accounts of the human predicament as divergent expressions of one cross-cultural reality (against John Hick) or as incommensurably different (against S. Mark Heim). Instead, serious comparison reveals "a complex and overlapping pattern of similarities and differences" under the aegis of their shared category (182-83). More narrowly, Thatamanil also inveighs against reading the great Advaita teaching "I am Brahman" in terms of mystical experience. Shankara is, according to this interpretation, better understood as "an apophatic theologian who rejects the idea that ultimate reality can be experienced" (61). In the light of this particular comparative example, the reigning stereotype is reversed: it is the Christian, rather than the Hindu, who emphasizes individual, ecstatic experiences of the Spirit as an integral feature of the religious quest.

Readers of this journal are perhaps among those least likely to subscribe to the simplistic caricatures of East and West that Thatamanil adopts as his foil. But this study works on yet another level that makes it worthy of note: that is, as a constructive contribution to philosophical 
Christian theology. As he sets Tillich and Shankara side-by-side, Thatamanil also notes flaws in their respective schemas: "In Sankara's case, failure to adhere rigorously to nondualism gives rise to a tendency to define away the world as unreal. In Tillich's case, his belief that freedom requires separation between God and creature gives rise to a tragic vision of human life as inevitably compromised by ineradicable ambiguity" (92). Both difficulties can, moreover, be traced to a common source: a "substantialist conception of ultimate reality" (166). In the interest of constructing, an alternative, the book's final chapter mines the work of contemporary Christian philosophers Joseph Bracken and Neville himself, proposing a "dynamic apophatic nondualism" that re-casts divine ultimacy in terms of creative activity rather than substantial existence. By making such a metaphysical move, Thatamanil argues, one can preserve the best insights of both traditions without falling prey to what turns out to be simply more subtle and insidious forms of dualișm.

Unsympathetic critics of The Immanent Divine will no doubt challenge Thatamanil's alternative. It seems dubious, at the very least, to suggest that the riddle of divine immanence can be resolved by appeal to a couple of contemporary North Americans. Why the laborious comparison, spanning twelve centuries, if a more compelling answer can be found so close to home? A case can be made, however, that authentic interreligious study invariably leads the interpreter home, albeit to a home that has been de-familiarized and transformed by the comparative exercise. In the case of Thatamanil, this home is self-evidently the $20^{\text {th }}$-century liberal Protestantism of Paul Tillich and his interpreters. The great virtue of The Immanent Divine is not that it shakes off this tradition, but that it pursues the tradition's normative theological agenda in a comparative mode. When Thatamanil announces his desire to take up "Tillich's unfulfilled intention", to rewrite his systematic theology in dialogue with "the world's religious traditions" (8), the wisest course would be to take him at his word and to judge his constructive proposal accordingly.

Indeed, as is so often the case in these kinds of studies, it may well turn out that the final conclusions possess less intrinsic value than the comparison itself. It is precisely when Thatamanil is struggling with particularsarguing the persistence of worldly activity in the life of the liberated self-knower, for example, or interpreting ecstasy as a mode of human living rather than as an isolated event-that his writing is most persuasive. These are the discussions that most strongly held my interest and to which I expect to find myself returning in years to come. The various parts of The Immanent Divine are thus, I suggest, ultimately and ironically greater than the whole.

Reid B. Locklin

University of Toronto

\section{Christians Meeting Hindus. An Analysis and Theological Critique of the Hindu-Christian Encounter in India. Bob Robinson. Carlisle, Cumbria, UK and Waynesboro, GA, USA: Regnum, 2004, $392+$ xviii} pp.

THIS book justifiably earned a place among a small group of finalists for the Society of HinduChristian Studies book award for publications appearing between 2003 and 2005. The author, who teaches at the Tyndale Graduate School of Theology in New Zealand, earned a doctorate in 1992 at the University of London under the guidance of Geoffrey Parrinder. Although the present volume grows out of that dissertation, it has been substantially updated and expanded to include literature through the year 2000. Robinson spent extensive time in India in the 1980 s and 1990s in researching what has turned out happily to be a mine of information for scholars seeking extensive analysis and theological sources on a myriad of issues 